\title{
O LEGISLADOR COLETIVO NA FILOSOFIA DE CONDORCET
}

The collective legislator in Condorcet's philosophy

Patrícia Carvalho Reis *

Resumo: O presente artigo tem o objetivo de analisar a ideia de quem são os responsáveis por fazer as leis na filosofia de Condorcet. Como analisaremos, segundo Condorcet, os cidadãos devem interferir na atividade legislativa juntamente com seus representantes. Segundo Condorcet, o direito de soberania está diretamente relacionado com a possibilidade de os cidadãos afirmarem as leis as quais querem ser submetidos. Como eles não podem fazer isso diretamente devem delegar algumas tarefas relacionadas com a feitura das leis aos representantes, mas permanecer com outras. Ao atuarem na feitura das leis, os cidadãos são livres. Além disso, essa atuação impede a existência de insurreições, pois os cidadãos terão o direito de mostrar suas vozes sobre a política de modo pacífico e constante.

Palavras-chave: Direito de soberania, Poder legislativo, Cidadãos, Representantes.

Abstract: This article aims to analyse the idea of who is responsible for making the laws in Condorcet's philosophy. According to the philosopher, citizens must participate in legislative activity together with their representatives. He believed that the right of sovereignty was directly related to the possibility for citizens to choose which laws they wanted to be submitted to. As they could not do so directly, they had to delegate some tasks related to the making of laws to their

* Graduada em Direito, Mestre e Doutora em Filosofia Política pela Universidade Federal de Minas Gerais. Professora substituta da UFMG. Artigo enviado em 20/11/2017 e aprovado para publicação em 26/10/2018. 
representatives, but keep others. By participating in the law-making process, citizens were free. Moreover, it prevented insurrections, since citizens had the right to express their opinions on politics in a peaceful and continuous manner.

Key-words: Right of sovereignty, Legislative power, Citizens, Representatives.

$\mathrm{E}$ m 9 de agosto de 1792, Condorcet, deputado da Assembleia Legislativa da França, ${ }^{1}$ afirma o que entende por soberania no texto Instrução sobre o exercício do direito de soberania:

O direito de fixar as regras gerais às quais serão submetidas as ações que não podem ser abandonadas à vontade individual, ou que devem ser feitas em nome da sociedade e por seus agentes; esse direito que constitui aquilo que nós chamamos de soberania $(\ldots)^{2}$

Assim, para esse filósofo, a soberania corresponde à atividade de fixar as regras gerais de uma sociedade. Em outras palavras, a soberania está diretamente relacionada com a atividade legislativa. Esse pensamento de Condorcet nos mostra a influência que recebeu de Rousseau. ${ }^{3}$ No Contrato Social, Rousseau também relaciona a soberania à lei: "Assim, por exemplo, tiveram-se por atos de soberania o ato de declarar guerra e o de fazer a paz, que não o são, pois cada um desses atos não é uma lei, mas unicamente uma aplicação da lei, um ato particular que determina o caso da lei". ${ }^{4}$ Desse modo, Rousseau faz uma distinção entre o ato de soberania e o ato de governo: o primeiro diz respeito à lei; o segundo, à aplicação da lei.

Como salienta Robert Derathé, para Rousseau, a potência executiva está relacionada com a força, enquanto a potência legislativa, com a vontade. ${ }^{5}$ Isso, por sua vez, não significa que a potência executiva ou a força não tenha relação com a soberania. Nas palavras de Rousseau, tal potência

\footnotetext{
${ }^{1} \mathrm{Tal}$ assembleia foi instaurada em $1^{\circ}$ de outubro de 1791 após a dissolução da Assembleia Nacional, também chamada de Assembleia Constituinte. Ela era composta por 745 deputados. Como afirma Simon Schama, em termos de talento político e intelectual, a Legislativa foi a mais impressionante das assembleias revolucionárias. In: SCHAMA, Simon. Cidadãos: uma crônica da Revolução Francesa. São Paulo: Companhia das Letras, 1989, p. 473

${ }^{2}$ CONDORCET, Nicolas de. Instruction sur l'exercice du droit de souveraineté. In Oeuvres de Condorcet. Paris: Firmin Didot Frères, 1847. Tome X, p. 535. As traduções quando não indicadas são da própria autora.

${ }^{3}$ Como ressalta Newton Bignotto, O Contrato Social, publicado em 1762, foi a maior influência teórica dos atores da Revolução. In: BIGNOTTO, Newton. As aventuras da virtude: as ideias republicanas na França do século XVIII. São Paulo: Companhia das Letras, 2010, p. 233.

${ }^{4}$ ROUSSEAU, Jean-Jacques. Do Contrato Social. São Paulo: Nova Cultural, 1987, p.45.

${ }^{5}$ DERATHÉ, Robert. Jean-Jacques Rousseau e a ciência de seu tempo. Editora Barcarolla; Discurso Editorial, 2009, p. 425-426.
} 
constitui uma emanação da soberania. ${ }^{6}$ Como acrescenta Derathé, a separação dos poderes não tem, em Rousseau, o mesmo sentido nem o mesmo alcance que em Montesquieu. Segundo o filósofo genebrino, deve ocorrer uma subordinação estrita e constante do executivo ao legislativo. ${ }^{7}$ Montesquieu, apesar de afirmar que o poder judiciário não é tão forte quanto os demais poderes, não defende que o poder executivo deve ser subordinado ao legislativo. ${ }^{8}$

Ao associar a soberania com o ato de criar as leis, observamos que Condorcet também parece concordar que haja uma supremacia dessa atividade em relação à de aplicação da lei. No já mencionado texto Instrução sobre $o$ exercício do direito de soberania, Condorcet afirma que a soberania "pertence ao povo, quer dizer, à universalidade dos cidadãos que ocupam um território, e pode pertencer apenas a ele". ${ }^{9}$ No texto Reflexões sobre os poderes $e$ as instruções a dar pelas províncias aos seus deputados nos Estados Gerais, de 1789, Condorcet reafirma essa ideia de modo indireto:

É, portanto, impossível pretender que um só ou mais indivíduos tenham o direito, a seu prazer e para seu interesse particular, de fazer mover todas as forças da sociedade, de dirigi-las contra ela mesma, de prescrever as regras que seriam apenas uma vontade isolada; em uma palavra, de gozar do poder legislativo. ${ }^{10}$

Segundo Condorcet, uma pessoa não pode afirmar quais regras vão vigorar numa sociedade pelo fato de isso ferir o direito da igualdade. Como ele afirma, a igualdade é um dos direitos naturais dos homens, o qual implica que eles participem da confecção de suas leis e de todos os atos feitos em nome da sociedade. ${ }^{11}$

O pensamento de que a soberania não pode ser atribuída a uma pessoa é também expresso no artigo 28 da Declaração de direitos dos homens, de fevereiro de 1793: "Nenhuma reunião parcial de cidadãos, e tampouco algum

${ }^{6}$ ROUSSEAU, ibidem.

${ }^{7}$ DERATHÉ, op. cit. p.445.

${ }^{8}$ MONTESQUIEU. Do Espírito das Leis. São Paulo: Abril Cultural, 1979, p. 151. Segundo Montesquieu, o poder executivo também interfere na feitura das leis por meio do veto. Além disso, como demonstraremos, para Rousseau, diferentemente de Montesquieu, o povo atua na feitura das suas leis.

${ }^{9}$ CONDORCET, Nicolas de. Instruction sur l'exercice du droit de souveraineté, op. cit., p. 535. Marsílio de Pádua, no seu livro Defensor pacis, publicado em 1324, já defendia que o consentimento popular é o fundamento do bom governo. Segundo ele, o legislador ou a causa eficiente primeira e específica da lei é o povo ou o conjunto dos cidadãos por meio da vontade externada verbalmente no seio de sua assembleia geral, prescrevendo que algo deve ser feito ou não, sob pena de castigo ou punição temporal. In: PÁDUA, Marsílio de. O defensor da paz. Petrópolis: Editora Vozes, 1997, p. 130-133.

${ }^{10}$ CONDORCET, Nicolas de. Réflexions sur les pouvoirs et instructions à donner par les provinces à leurs députés aux états généraux, op. cit, Tome IX, p. 270-271.

${ }^{11}$ CONDORCET, Nicolas de. De l'Influence de la Révolution d'Amérique sur l'Europe, op. cit. Tome VIII, p. 6. 
indivíduo, pode atribuir a si a soberania (...)". ${ }^{12}$ Tais ideias já tinham sido defendidas por Rousseau. Numa passagem do Contrato Social, o filósofo genebrino afirma: “Que será, pois, propriamente, um ato de soberania? Não é uma convenção entre o superior e o inferior, mas uma convenção do corpo com cada um de seus membros (...)" ${ }^{13}$ Em outra passagem dessa obra, sustenta que a existência de um senhor faz destruir o corpo político, uma vez que súditos submetidos a um senhor não constituem um povo: "Trata-se, caso se queira, de apenas de uma agregação, mas não de uma associação; nela não existe nem bem público, nem corpo político" ${ }^{14}$ Desse modo, para Rousseau, num corpo político, um indivíduo não deve impor regras aos outros. Pelo contrário, as pessoas devem se submeter às regras com as quais elas próprias consentiram. Em outras palavras, o governo legítimo não é fundado na força ou numa ordem transcendente, mas em acordos ou convenções estabelecidos entre as próprias pessoas que se submeterão às regras desses acordos.

Como afirma Derathé, Rousseau não sustenta que a potência emana de Deus, nem no rei ou nos principais do Estado, ele faz do povo o único soberano. ${ }^{15}$ Isso significa que o governo, detentor da força pública, deve curvar-se à vontade do povo. Diante dessas considerações, percebemos que Condorcet, assim como Rousseau, não defende a soberania do rei, mas a soberania popular. ${ }^{16}$

Esse pensamento, apesar de já ter sido demonstrado antes, contrariava a tradição baseada no direito divino dos reis, em que o poder destes era baseado num argumento transcendente. Como já mencionamos, Condorcet - assim como Rousseau - afirma que a soberania pertence ao povo. Seguindo esse pensamento, para Condorcet, não se pode afirmar que cada assembleia seja soberana, uma vez que a soberania somente pode pertencer à universalidade do povo. ${ }^{17}$

\footnotetext{
${ }^{12}$ CONDORCET, Nicolas de. Escritos políticos-constitucionais Condorcet. Organização, tradução e apresentação: Amaro de Oliveira Fleck e Cristina Foroni. Prefácio: Newton Bignotto. Campinas: Editora Unicamp, 2013, p. 128.

${ }^{13}$ ROUSSEAU, Jean-Jacques. op. cit., p. 50.

${ }^{14}$ ROUSSEAU, Jean-Jacques, op. cit. p. 30.

${ }^{15}$ DERATHÉ, Robert, op. cit., p. 88.

${ }^{16}$ É oportuno ressaltar que, após os representantes do Terceiro Estado se declararem membros de uma Assembleia Nacional, a maioria dos deputados requeria uma redefinição do papel do monarca, mas não o fim da monarquia. Entretanto, após a tentativa de fuga do rei Luís XVI e sua família, em 21 de junho de 1791, muitas pessoas passaram a defender expressamente a instauração do regime republicano na França. Condorcet é uma delas. No seu texto Da República ou um rei é necessário para a conservação da liberdade?, publicado em 12 de julho de 1791, critica os argumentos utilizados por alguns a favor da monarquia. Entretanto, o momento da instauração da república no território francês somente se concretizou alguns meses depois, em setembro de 1792.

${ }^{17}$ CONDORCET, Nicolas de. Projet de Constitution française, op. cit. Tome XII, p. 347.
} 
Além disso, seguindo as ideias já defendidas por Rousseau, para Condorcet, a soberania é inalienável. ${ }^{18}$ Como defende Rousseau, assim como não é possível a alguém alienar sua liberdade a outra pessoa, não há como um povo alienar seu direito de soberania aos governantes. ${ }^{19}$ Desse modo, o direito de o povo escolher as regras às quais será submetido e o direito de liberdade não podem ser retirados dele, ainda que consinta com essa perda:

Se, pois, o povo promete simplesmente obedecer, dissolve-se por esse ato, perde sua qualidade de povo - desde que há um senhor, não há mais um soberano e, a partir de então, destrói-se o corpo político. ${ }^{20}$

Alguns teóricos discordam da ideia de que os indivíduos não podem transferir a outro o poder de ditar as regras da sociedade. Segundo eles, pelo pacto de submissão, as pessoas podem transmitir seu poder a um príncipe, o que faria com que este se tornasse o único soberano do Estado. Esse pensamento é defendido por Thomas Hobbes. Numa passagem da sua obra Leviatã, publicada em 1651, afirma que uma das formas de se obter o poder soberano ocorre quando os homens concordam entre si em se submeterem a um homem ou a uma assembleia de homens, voluntariamente, confiando que serão protegidos por esse homem ou essa assembleia contra os outros. ${ }^{21}$

Dessas considerações, percebemos que, para Condorcet, assim como para Rousseau, a soberania relaciona-se com a atividade legislativa, pertence ao povo e é inalienável. Diante disso, estamos prontos para tratar de outra característica da soberania na filosofia de Condorcet: sua delegabilidade parcial. Isso significa que, para Condorcet, o exercício da soberania pode ser dividido.

Como mencionamos acima, para Condorcet, o povo pode delegar uma parte do exercício da soberania: “(...) o povo pode delegar o exercício desse direito inalienável". ${ }^{22}$ Isso significa que Condorcet faz uma diferenciação entre posse e exercício da soberania. Os cidadãos detêm a posse da soberania, enquanto o exercício da soberania pode ser delegado aos representantes. Assim, podemos afirmar que a posse da soberania para Condorcet é inalienável. Entretanto, seu exercício é delegável. Percebemos, portanto, que a representação é uma consequência do direito de soberania do povo.

\footnotetext{
${ }^{18}$ CONDORCET, Nicolas de. Instruction sur l'exercice du droit de souveraineté, op. cit. Tome X, p. 535.

${ }^{19}$ ROUSSEAU, Jean-Jacques, op. cit. p. 26.

${ }^{20}$ ROUSSEAU, Jean-Jacques, op. cit. p. 44.

${ }^{21}$ Segundo Hobbes, o soberano tem o direito de taxar, fazer a paz, comandar o exército, decidir, julgar, legislar. In: HOBBES, Thomas. Leviatã, ou matéria, forma e poder de um estado eclesiástico e civil. Organizado por Richard Tuck. $2^{\underline{a}}$ ed. São Paulo: Martins Fontes, 2008, p. 148-155.

${ }^{22}$ CONDORCET, Nicolas de. Instruction sur l'exercice du droit de souveraineté, op. cit. Tome X, p. 535 .
} 
Por outro lado, para Rousseau, a soberania deve sempre residir no povo e este não pode confiar seu exercício aos representantes. ${ }^{23} \mathrm{Em}$ outras palavras, de acordo com Rousseau, o único Estado legítimo é aquele em que o próprio povo exerce a soberania:

A soberania não pode ser representada pela mesma razão por que não pode ser alienada, consiste essencialmente na vontade geral e a vontade absolutamente não se representa. É ela mesma ou é outra, não há meio-termo. ${ }^{24}$

Segundo Rousseau, quando um povo elege representantes e lhes dá um mandato para que exerçam em seu lugar e em seu nome a potência legislativa, ele se desfaz do poder supremo e abdica, assim, a soberania. É com base nesse argumento que Rousseau critica o governo da Inglaterra: “O povo inglês pensa ser livre, mas engana-se muito: ele só o é durante a eleição dos membros do parlamento; tão logo são eleitos, ele é escravo, ele não é nada". ${ }^{25}$

Dessas considerações, podemos afirmar que Rousseau era mais exigente do que Condorcet no que diz respeito à atuação dos cidadãos na feitura das leis, uma vez que, para aquele, os cidadãos não poderiam deixar que outras pessoas exercessem em seu nome a atividade legislativa.

Assim, Rousseau critica a ideia de que os deputados do povo façam as leis de acordo com suas vontades particulares. A única forma de assegurar que a vontade particular é conforme a vontade geral é quando aquela vontade for submetida aos sufrágios livres do povo. ${ }^{26}$ Como consequência, Rousseau defende que os deputados do povo não podem estabelecer as leis sem que haja uma ratificação do povo: "Toda lei que o povo em pessoa não ratificou é nula; não é uma lei" ${ }^{27}$

Como nos esclarece Derathé, para Rousseau, o povo pode designar os deputados, com a condição de que estes se limitem a preparar, propor e redigir as leis, o povo permanecendo livre para ratificá-las ou rejeitá-las por seus sufrágios. ${ }^{28}$ Quando os próprios deputados votam as leis, eles se tornam, durante toda a duração de seu mandato, os únicos senhores do Estado. ${ }^{29}$

\footnotetext{
${ }^{23}$ Como salienta Derathé, depois da escrita do Contrato Social, Rousseau, no lugar de descartar sistematicamente o governo representativo, teria se contentado em reformá-lo. In: Derathé, Robert, op. cit., p. 409.

${ }^{24}$ ROUSSEAU, Jean-Jacques, op. cit. p. 108.

${ }^{25}$ ROUSSEAU, Jean-Jacques, ibidem.

${ }^{26}$ ROUSSEAU, Jean-Jacques, op. cit. p. 58.

${ }^{27}$ ROUSSEAU, Jean-Jacques, op. cit. p. 108.

${ }^{28}$ Percebemos, assim, que, para Rousseau, os membros do governo também interferem na feitura das leis. Desse modo, o filósofo genebrino, apesar de, à primeira vista, ser contra o sistema representativo, atribui funções aos delegados do povo na tarefa legislativa.

${ }^{29}$ DERATHÉ, Robert. Jean-Jacques Rousseau e a ciência de seu tempo. São Paulo: Discurso Editorial, 2009, p. 392.
} 
É importante também ressaltar a ideia de que, para Condorcet, a delegação do exercício da soberania não implica a perda desse direito, uma vez que o povo continua a ser seu detentor. Em decorrência disso, Condorcet afirma que o povo conserva o direito de retirar os poderes que ele deu:

Ele [o povo] pode delegar o exercício desse direito inalienável; nesse caso, como ele conserva por essa porção mesma, aquele de retirar os poderes que deu, seu direito permanece sempre em toda sua plenitude e independência absoluta. ${ }^{30}$

Segundo Condorcet, a entrega de algumas funções soberanas aos representantes é importante, pois, em sociedades extensas, é inviável os cidadãos elaborarem suas leis diretamente ${ }^{31}{ }^{2}$ Em outras palavras, o iluminista reconhece que o regime em que os cidadãos elaboram suas leis, sem a interferência dos representantes, somente pode existir em pequenos Estados.

A ideia de que a república somente poderia existir em pequenos territórios era comum no pensamento dos iluministas que antecederam Condorcet. Voltaire, por exemplo, ao tratar da democracia no seu Dicionário filosófico afirma que ela só parece convir a um país muito pequeno. ${ }^{32}$ Montesquieu, na obra Do Espírito das Leis, sustenta que os pequenos Estados tendem a ser repúblicas; os de tamanho médio, monarquias; e os grandes impérios, despóticos. ${ }^{33}$

Apesar de Condorcet estar de acordo com que os cidadãos possam fazer diretamente suas leis somente em pequenos Estados, ele extrapola esse pensamento ao defender que, nos grandes Estados, os cidadãos podem fazer as leis junto a seus representantes. Nas notas que escreveu sobre o mencionado verbete escrito por Voltaire, Condorcet afirma o que entende por democracia em grandes territórios:

Se nós entendemos por democracia uma constituição na qual a assembleia geral dos cidadãos faz imediatamente as leis, é claro que a democracia convém apenas a um pequeno Estado. Mas, se nós a entendemos como uma constituição em que todos os cidadãos divididos em várias assembleias elegem os deputados encarregados de representar e de levar a expressão geral das vozes dos seus comitentes a uma assembleia geral que representa a nação, é fácil ver que essa constituição convém a grandes Estados. ${ }^{34}$

\footnotetext{
${ }^{30}$ CONDORCET, Nicolas de. Instruction sur l'exercice du droit de souveraineté, op. cit. Tome X, p. 535.

${ }^{31}$ CONDORCET, Nicolas de. De la nature des pouvoirs politiques dans une nation libre. In Oeuvres de Condorcet. Organização A. Condorcet, o'Connor e F. Arago. Paris: Firmin Didot Frères, 1847. Tome X, p. 592.

${ }^{32}$ VOLTAIRE. Democracia. In: Dicionário Filosófico. Seleção de textos de Marilena de Souza Chauí. Tradução de Marilena de Souza Chauí. 2ª ed. São Paulo: Abril Cultural, 1978, p. 147.

${ }^{33}$ MONTESQUIEU. Do Espírito das Leis. São Paulo: Abril Cultural, 1979, p. 122.

${ }^{34}$ CONDORCET, Nicolas de. Notes sur Voltaire. op. cit. Tome XII, p. 393.
} 
Outro autor contemporâneo de Condorcet que concilia as ideias de representação e democracia é Thomas Paine. ${ }^{35}$ Na segunda parte de sua obra Direitos dos Homens, de 1792, descreve o que considera ser um regime republicano. Na sua visão, o governo republicano é estabelecido e conduzido para o interesse público, tanto individualmente quanto coletivamente. Ao prosseguir seu raciocínio, afirma que o regime republicano pode ocorrer nos locais de grande extensão territorial e grande população desde que haja representação. Como acrescenta, a democracia simples (sociedade em que os cidadãos se governam sem a ajuda de meios secundários) não pode existir em grandes territórios com grande população. ${ }^{36}$ Assim, esses autores conciliam a ideia de democracia e representação, que, por sua vez, configurará o que Condorcet denomina de "democracia representativa". ${ }^{37}$ Bignotto demonstra a importância que esses pensamentos de Condorcet e Paine tiveram naquele período:

Rousseau fornecera a gramática do pensamento republicano, mas sua adesão à ideia de democracia direta como a expressão do governo mais capaz de realizar a liberdade na história acabou reforçando a noção de que uma república era impossível nas condições modernas. Com Paine e Condorcet, um novo vocabulário se instaura, apontando para um republicanismo livre dos impasses que dominaram o século. A associação entre república e representação foi a chave para um novo universo conceitual, no qual o "último iluminista" evoluiu com segurança e brilho. ${ }^{38}$

\footnotetext{
${ }^{35}$ Paine esteve na França pela primeira vez em 1781. Provavelmente nesse ano ele se encontrou com Condorcet na casa de Benjamin Franklin. Entretanto, foi na sua segunda viagem à Paris, por três meses no ano de 1787, que Paine e Condorcet estreitaram sua relação de amizade. In: BADINTER, Elisabeth; BADINTER, Robert. Condorcet. Un intellectuel en politique. Paris: Fayard, 1988, p. 227. A partir de 1791, Paine está novamente na França e, junto a Condorcet, Brissot, Duchâtelet e Bonneville fundam em junho desse ano "A Sociedade Republicana". Ressaltamos, ainda, que, em $1^{\circ}$ de julho de 1791, Paine redige o Manifesto Republicano, endereçado a todos os cidadãos franceses. Ele foi traduzido por Sophie de Condorcet (esposa de Condorcet) e assinado conjuntamente por Paine e Duchâtelet. In: MAAMARI, Adriana Mattar. A República e a Democracia em Thomas Paine. 2007. 205 f. Tese (Doutorado em Filosofia) - Departamento de Filosofia, Universidade de São Paulo, São Paulo), p. 75. Ademais, Paine e Condorcet pertenceram ao Comitê de Constituição responsável por elaborar o projeto constitucional francês apresentado em fevereiro de 1793.

${ }^{36}$ PAINE, Thomas. Rights of man. Penguin Books, London, 1987, p. 178-180.

${ }^{37}$ Condorcet utiliza o termo "democracia representativa" na obra Cartas de um burguês de New Haven, de 1788 (p. 84) e no texto Aos amigos da liberdade sobre os modos de assegurar a duração dela, de 1790 (p. 179). Como salienta Pierre Rosanvallon, antes de 1793, o termo "democracia representativa" já tinha sido mencionado por Condorcet, Paine e Brissot, mas não discutido. Em 1793, um vocabulário político novo aparece como "república democrática", "república popular", "constituição democrática" e mesmo "soberania representativa". Entretanto, como ressalta esse intérprete, as pessoas que empregavam esses termos pensavam em formas diversas de colocá-los em prática. In: ROSANVALLON, Pierre. La démocratie inachevée. Histoire de la souveraineté du peuple en France. Paris: Éditions Gallimard, 2000, p. 57-58). Aliás, mesmo nos nossos dias, observamos um grande número de significados para essas expressões.

${ }^{38}$ BIGNOTTO, Newton. As aventuras da virtude: as ideias republicanas na França do século XVIII. São Paulo: Companhia das Letras, 2010, p. 275.
} 
Numa passagem do já mencionado texto Instrução sobre o exercício do direito de soberania, Condorcet afirma que o povo não precisa delegar todas as funções soberanas; ele pode permanecer com algumas, como, por exemplo, as relacionadas com o poder de mudar as leis constitucionais. Assim, essa porção do poder soberano pode ser exercida pelo povo. Porém, caso queira delegar essa parte da soberania, o povo pode fazê-lo. ${ }^{39}$ Entretanto, Condorcet parece estar convicto de que o povo não deve delegar o direito de fazer as leis de modo integral aos representantes. Baseando-se nessa ideia, na sua já mencionada obra Cartas de um burguês de New Haven, afirma que “(...) todo corpo que tivesse um poder ilimitado de fazer leis é perigoso para a liberdade, qualquer que seja sua forma". ${ }^{40}$

Diante dessas considerações, podemos afirmar que, para Condorcet, a atuação tanto dos cidadãos quanto dos representantes na feitura das leis não é algo impossível ou indesejado. Como consequência, segundo o iluminista, os representantes não devem ser os únicos a exercer a soberania. Cidadãos e representantes devem exercer um trabalho interdependente na atividade legislativa.

Assim, percebemos que, para Condorcet, as leis e a Constituição não devem ser obras de alguns. Desse modo, Condorcet critica não apenas o exercício da atividade legislativa por um rei absoluto, como também seu exercício apenas por alguns representantes eleitos pelos cidadãos. Como já afirmamos, segundo o iluminista, as ideias de representação e democracia direta não são contraditórias, mas complementares.

Condorcet utiliza o exemplo americano para dar força a suas ideias. $\mathrm{Na}$ obra Esboço de um quadro histórico dos progressos do espírito humano, de 1794, Condorcet constata que os americanos, após a independência da Inglaterra e a proclamação da república, passaram a desempenhar a atividade legislativa:

(...) como, em uma grande nação, necessariamente dispersa e dividida em um grande número de assembleias isoladas e parciais, ousou-se, pela primeira vez, conservar para o povo o seu direito de soberania, o direito de não só obedecer a leis, cujo modo de formação, se este é confiado a representantes, tenha sido legitimado por sua aprovação imediata; leis das quais, se elas ferem seus direitos ou seus interesses, ele possa sempre obter a reforma por um ato regular de sua vontade soberana. ${ }^{41}$

Desse trecho, percebemos que, nos Estados Unidos, apesar de ser um grande país, os cidadãos aprovam as leis feitas por seus representantes e

\footnotetext{
${ }^{39}$ CONDORCET, Nicolas de. Instruction sur l'exercice du droit de souveraineté, op. cit. Tome X, p. 535.

${ }^{40}$ CONDORCET, Nicolas de. Lettres d'un bourgeois de New Haven a un citoyen de Virgine, sur l'inutilité de partager le pouvoir légistatif entre plusieurs corps. op. cit. Tome IX, p. 57. ${ }^{41}$ CONDORCET, Nicolas de. Esboço de um quadro histórico dos progressos do espírito humano. Tradução de Carlos Alberto Ribeiro de Moura. Apresentação de Maria das Graças de Souza. Campinas. Editora Unicamp, 1993, p. 153.
} 
também podem requerer, a qualquer momento, a reforma delas, no caso de ferirem seus direitos. Desse modo, os americanos não obedecem passivamente às ordens de um governante: eles demonstram suas vozes no processo de feitura de suas leis. Assim, o exemplo dos Estados Unidos comprovava que a atuação dos cidadãos na feitura das leis em grandes territórios podia ser efetivada no plano concreto e que não era apenas uma referência teórica. Por sua vez, Condorcet percebe que esse exercício da soberania pelos cidadãos somente é viável se os representantes também exercerem uma parte do direito de soberania.

Analisando esse pensamento de Condorcet, Rosanvallon afirma que o iluminista procura encontrar um tipo de posição intermediária entre aquilo que poderia chamar de soberania selvagem do povo, que se exprime na espontaneidade da revolta ou na expressão difusa da soberania, e a soberania organizada, que é posta em obra pelo procedimento eleitoral. ${ }^{42}$ Gabriele Magrin também parece concordar com essas ideias. Segundo o intérprete italiano, Condorcet tenta evitar o despotismo da assembleia de um lado e, de outro, uma expressão violenta da vontade popular. Assim, Condorcet imagina uma articulação "flexível" entre a representação e a democracia. ${ }^{43}$

Percebemos, portanto, que Condorcet tenta achar uma alternativa entre o modelo político em que apenas os representantes legislam e aquele em que os cidadãos atuam diretamente na política sem a interferência de representantes. Ora, por que deve existir um ou outro? Por que não se pode conciliar um com o outro? Utilizando o termo empregado por Rosanvallon, consideramos que Condorcet defende a "plasticidade" das instituições políticas. Isso significa que, para Condorcet, um regime político não precisa ser apenas democrático ou apenas representativo. Pode haver uma maleabilidade entre esses dois conceitos.

No nível abstrato, Condorcet reconhece que uma sociedade em que os cidadãos atuam na feitura das leis diretamente tende a delegar aos representantes uma parte da atividade legislativa e permanecer com outra à medida que a população cresce. Mas o que fazer nas sociedades em que as pessoas não têm o hábito de interferir na feitura das leis e apenas uma pessoa ou algumas são responsáveis por essa atividade? ${ }^{44} \mathrm{~A}$ solução proposta por Condorcet se baseia na instituição de um texto constitucional e uma Declaração de Direitos estabelecendo novos parâmetros pelos quais tais sociedades devem ser governadas. Assim, os legisladores fariam leis que

\footnotetext{
${ }^{42}$ ROSANVALLON, Pierre. op. cit., p. 73.

${ }^{43}$ MAGRIN, Gabriele. Condorcet: un constituzionalismo democratico. Milano: Francoangeli, 2001, p. 131.

${ }^{44}$ Não podemos esquecer que Condorcet é filósofo e homem político. Assim, muitas das suas ideias têm o objetivo de ser aplicadas no plano concreto. Em decorrência disso, podemos observar que, diferentemente de outros filósofos, Condorcet não se interessa, apenas, por assuntos com um grande nível de abstração.
} 
possibilitariam aos cidadãos também participar da atividade legislativa. Esse caminho foi o defendido por Condorcet quando era deputado da Convenção e um dos principais responsáveis pela feitura da Constituição de fevereiro de 1793. Desse modo, naquele momento em que apenas algumas pessoas legislavam e a atuação dos cidadãos na feitura das leis era inexistente, Condorcet elabora um projeto constitucional com artigos dispondo que os membros do poder legislativo não deveriam ser os únicos a legislar. Os cidadãos deveriam exercer essa atividade com eles. Portanto, Condorcet, na função de legislador, defende que ele e seus pares não deveriam ser os únicos autores das leis.

Poderíamos pensar, num primeiro momento, que é contraditório Condorcet, sem a participação dos cidadãos, criar leis cujo conteúdo dispõe que a atividade legislativa deve ser exercida não somente pelos representantes, mas, também, pelos cidadãos. Porém, logo mudamos nossa interpretação. Ora, a passagem de um regime em que poucos legislam para outro em que os cidadãos atuam na feitura das leis junto a seus representantes não ocorre de modo espontâneo. É como se o direito de os cidadãos intervirem na atividade legislativa tivesse que ser reconhecido e posto numa lei pelos que estão exercendo, de fato, tal atividade. Caso os representantes não façam isso espontaneamente, Condorcet defende que os cidadãos requeiram, de modo pacífico, que esse seu direito lhes seja conferido. ${ }^{45}$

Como já ressaltamos, a Constituição não deve apenas dispor que os cidadãos participem da atividade legislativa. Ela deve criar meios pelos quais essa participação seja constante. Assim, a Constituição deve ser o instrumento que incitará a atuação dos cidadãos na atividade legislativa e, consequentemente, possibilite que o exercício da soberania pelos cidadãos esteja sempre em atividade.

É importante salientar ainda que, para Condorcet, os cidadãos, além de intervirem na feitura das suas leis, devem demonstrar suas vozes de outras maneiras nos assuntos que lhes dizem respeito, como: vigiando seus representantes, ${ }^{46}$ ingressando com ações contra estes, ${ }^{47}$ elegendo-os... ${ }^{48}$. De

\footnotetext{
${ }^{45} \mathrm{Na}$ hipótese de os cidadãos não serem ouvidos pelos representantes, Condorcet reconhece que a insurreição pode ser a última alternativa de os primeiros demonstrarem suas vozes. ${ }^{46}$ Como afirma Rosanvallon, para algumas pessoas, a principal atuação dos cidadãos na política deveria ser vigiar seus representantes. Os que defendiam essa ideia apresentavam meios distintos pelos quais essa vigilância poderia ser exercida. Alguns a imaginavam e a praticavam sob a forma diretamente ativa de uma presença na rua, nos clubes e nas tribunas do público na Assembleia. Entretanto, como salienta esse intérprete, o maior número daqueles que exaltavam a vigilância dos cidadãos considerava que seu exercício estaria relacionado sobretudo com o poder de opinião, diretamente relacionado com a liberdade de imprensa. In: ROSANVALLON, Pierre, op. cit., p. 44- 45. Para esses, os cidadãos deveriam exercer esse poder de modo informal, não institucionalizado.

${ }^{47}$ CONDORCET, Nicolas de. Projet de Constitution française. op. cit. Tome XII. Título VIII, art. $1^{\circ}$.

${ }^{48}$ Ibidem. Título V, Seção II, art. $1^{\circ}$; Título VII, Seção I, art. $2^{\circ}$.
} 
acordo com as considerações apresentadas anteriormente, nessas situações, eles atuariam na política, sem exercer, propriamente, o direito de soberania.

Segundo Condorcet, a participação dos cidadãos na feitura de suas leis tem relação com o direito de liberdade. A partir do momento em que os cidadãos participam da atividade legislativa, eles passam a decidir a quais regras querem se submeter. Assim, deixam de aceitar passivamente as leis a que se submeterão e passam a ser os protagonistas da política do seu país.

Ressaltamos que nem todos consideram que a liberdade esteja relacionada com a feitura das leis. Para alguns, está associada com a possibilidade de os cidadãos escolherem seus representantes. Segundo Condorcet, existe uma explicação para isso: os homens adquiriram o hábito de obedecer a outros homens; como consequência, eles pensam que a liberdade consiste no direito de se submeter a senhores escolhidos por eles mesmos. ${ }^{49}$

Além de Condorcet considerar que a atuação dos cidadãos na feitura das leis lhes garante a e, segundo o iluminista, a participação popular na atividade legislativa traz outros benefícios, como, por exemplo, o de impedir que os representantes legislem em benefício próprio. Como salienta Condorcet, existe uma tendência de os seres humanos procurarem privilégios:

(...) todo corpo consultado sobre sua própria constituição tende, por uma inclinação natural, a desejar, mesmo de muita boa-fé, tudo aquilo que aumenta sua autoridade e a importância de seus membros; criado hoje, terá necessidade amanhã de se defender de ser guiado por esse espírito de corpo que nasce no próprio instante no qual os homens se reúnem e contra o qual a sabedoria humana não pôde ainda achar uma prevenção. ${ }^{50}$

Nesse aspecto, as ideias de Condorcet se assemelham às de Montesquieu. Na obra Do Espírito das Leis, Montesquieu afirma que a experiência eterna mostra que todo homem que tem poder é tentado a abusar dele. ${ }^{51}$ Desse modo, Condorcet, assim como Montesquieu, não subestima a característica dos seres humanos de tentar se favorecer.

Segundo nossa opinião, quando grande parte dos cidadãos tem princípios éticos consolidados, há mais chances de seus representantes também terem condutas condizentes com tais princípios. Por outro lado, quando a maioria dos cidadãos não se preocupa com o bem público, há uma tendência de os representantes também não se preocuparem com esse assunto, uma vez que estão inseridos nessa cultura. $\mathrm{O}$ desinteresse pelo bem da coletividade pode ser tão intenso a ponto de as pessoas passarem a considerar a corrupção normal e a prática de atos éticos, excepcional.

\footnotetext{
${ }^{49}$ CONDORCET, Nicolas de. De la nature des pouvoirs politiques dans une nation libre. op.cit., Tome X, p. 589.

${ }^{50}$ CONDORCET, Nicolas de. Essai sur la constitution et les fonctions des assemblées provinciales. op. cit. Tome VIII, p. 119-120.

${ }^{51}$ MONTESQUIEU. Do Espírito das Leis. São Paulo: Abril Cultural, 1979, p. 148.
} 
Há uma inversão de valores, tendo em vista que o indivíduo prestigiado passa a ser aquele que pensa em se favorecer e o que pensa no interesse público é visto como utopista.

Condorcet salienta que o fato de os representantes atuarem com o fim de obter interesses pessoais torna-se mais nocivo quando os cidadãos não percebem isso. O iluminista utiliza o termo "despotismo indireto" para denominar tal situação. ${ }^{52}$ Nesse caso, os cidadãos são prejudicados e não sabem que quem lhes traz os danos são seus supostos defensores.

De acordo com Condorcet, outro benefício de os cidadãos atuarem na feitura das leis é evitar que eles se tornem indiferentes em relação à política ${ }^{53}$. Como já mencionamos, para Condorcet, a Constituição deve ser o instrumento que estimulará os cidadãos a participarem da atividade legislativa. Segundo o iluminista, a ausência de tais estímulos previstos na Constituição faz com que somente alguns tratem desse assunto. ${ }^{54}$

Outro motivo pelo qual os cidadãos devem participar da feitura das suas leis exposto por Condorcet é evitar as insurreições. Ora, se há meios institucionais pelos quais os cidadãos podem atuar na feitura de suas leis, eles não precisarão recorrer a insurreições para demonstrar suas vozes. Assim, a ausência de instrumentos legais que possibilitem aos cidadãos demonstrar suas vozes na política faz com que eles se tornem passivos em relação a esse assunto, ou, de modo contrário, violentos. Portanto, instituições democráticas que permitem aos cidadãos demonstrarem suas vozes na política tendem a aprisionar e canalizar as paixões revolucionárias.

Diante dessas considerações, percebemos que, para Condorcet, os cidadãos devem atuar na feitura das leis junto aos seus representantes. Assim, o último iluminista defende uma espécie de legislador coletivo, conceito do qual os cidadãos fazem parte. Ao defender essa ideia, Condorcet considera que os cidadãos não devem se sujeitar a mandamentos impostos por poucas pessoas, mas a regras em cuja feitura eles puderam interferir.

\section{Referências bibliográficas}

BADINTER, Elisabeth; BADINTER, Robert. Condorcet. Un intellectuel en politique. Paris: Fayard, 1988.

BAKER, Keith. Condorcet: raison et politique. Paris: Hermann, 1988.

BIGNOTTO, Newton. As aventuras da virtude: as ideias republicanas na França do século XVIII. São Paulo: Companhia das Letras, 2010.

${ }^{52}$ CONDORCET, Nicolas de. Ideais sobre o despotismo. op. cit., p. 32.

${ }^{53}$ CONDORCET, Nicolas de. Exposição dos princípios e dos motivos do plano de Constituição. op. cit., p. 119.

${ }^{54}$ Diferentemente de Condorcet, para determinadas pessoas, é um alívio o fato de não terem que participar da atividade legislativa, e apenas os representantes terem essa incumbência. 
BINOCHE, Bertrand. Introduction à De l'esprit des lois de Montesquieu. Paris: Presses Universitaires de France, 1998.

CÍCERO, Marco Túlio. Da república. Tradução e notas Amador Cisneiros. $2^{\underline{a}}$ ed. São Paulo: Edipro, 2011.

.Dos deveres. Tradução de Angélica Chiapeta; revisão da tradução Gilson César Cardoso de Souza. São Paulo: Martins Fontes, 1999.

CONDORCET, Nicolas de. De l'influence de la Révolution d'Amérique sur l'Europe. In Oeuvres de Condorcet. Organização A. Condorcet, o'Connor e F. Arago. Paris: Firmin Didot Frères, 1847, 12 vols. Tome VIII.

. Essai sur la constitution et les fonctions des assemblées provinciales. In Oeuvres de Condorcet. Organização A. Condorcet o'Connor e F. Arago. Paris: Firmin Didot Frères, 1847. Tome VIII.

. Idées sur le despotisme. In Oeuvres de Condorcet. Organização A. Condorcet o'Connor e F. Arago. Paris: Firmin Didot Frères, 1847. Tome IX.

. Lettres d'un bourgeois de New Haven a un citoyen de Virgine, sur l'inutilité de partager le pouvoir légistatif entre plusieurs corps. In Oeuvres de Condorcet. Organização A. Condorcet o'Connor e F. Arago. Paris: Firmin Didot Frères, 1847. Tome IX.

. Réflexions sur les pouvoirs et instructions à donner par les provinces à leurs députés aux états généraux. In Oeuvres de Condorcet. Organização A. Condorcet o'Connor e F. Arago. Paris: Firmin Didot Frères, 1847. Tome IX.

Instruction sur l'exercice du droit de souveraineté. In Oeuvres de Condorcet. Organização A. Condorcet o'Connor e F. Arago. Paris: Firmin Didot Frères, 1847. TomeX.

.. De la nature des pouvoirs politiques dans une nation libre. In Oeuvres de Condorcet. Organização A. Condorcet, o'Connor e F. Arago. Paris: Firmin Didot Frères, 1847. Tome X.

. De la république ou un roi est-il nécessaire à la conservation de la liberté? In Oeuvres de Condorcet. Organização A. Condorcet, o'Connor e F. Arago. Paris: Firmin Didot Frères, 1847. Tome XII.

Exposition des principes et des motifs du plan de constitution. In Oeuvres de Condorcet. Organização A. Condorcet o'Connor e F. Arago. Paris: Firmin Didot Frères, 1847. Tome XII.

Notes sur Voltaire. In Oeuvres de Condorcet. Organização A. Condorcet o'Connor e F. Arago. Paris: Firmin Didot Frères, 1847. Tome XII.

Projet de Constitution française. In Oeuvres de Condorcet. Organização A. Condorcet o'Connor e F. Arago. Paris: Firmin Didot Frères, 1847. Tome XII.

Esboço de um quadro histórico dos progressos do espírito humano. Tradução de Carlos Alberto Ribeiro de Moura. Apresentação de Maria das Graças de Souza. Campinas. Editora Unicamp, 1993.

Escritos politicos-constitucionais Condorcet. Organização, tradução e apresentação: Amaro de Oliveira Fleck e Cristina Foroni. Prefácio: Newton Bignotto. Campinas: Editora Unicamp, 2013. 
DERATHÉ, Robert. Jean-Jacques Rousseau e a ciência de seu tempo. São Paulo: Editora Barcarolla; Discurso Editorial, 2009.

GODECHOT, Jacques. A Revolução Francesa. Cronologia Comentada. Rio de Janeiro. Editora Nova Fronteira, 1989.

HOBBES, Thomas. Leviatã, ou matéria, forma e poder de um estado eclesiástico e civil. Organizado por Richard Tuck. 2a ed. São Paulo: Martins Fontes, 2008.

MAAMARI, Adriana Mattar. A República e a Democracia em Thomas Paine. 2007. 205 f. Tese (Doutorado em Filosofia)- Departamento de Filosofia, Universidade de São Paulo, São Paulo, 2007.

MAGRIN, Gabriele. Condorcet: un constituzionalismo democratico. Milano: Francoangeli, 2001.

MONTESQUIEU. Do Espírito das Leis. São Paulo: Abril Cultural, 1979.

PÁDUA, Marsílio de. O defensor da paz. Petrópolis: Editora Vozes, 1997.

PAINE, Thomas. Rights of man. Penguin Books, London, 1984.

ROBESPIERRE, Maximilien. Discursos e relatórios na Convenção. Tradução Maria Helena Franco Martins. Rio de Janeiro: EDUERJ, Contraponto, 1999.

ROSANVALLON, Pierre. La démocratie inachevée. Histoire de la souveraineté du peuple en France. Paris: Éditions Gallimard, 2000.

ROUSSEAU, Jean-Jacques. Do Contrato Social. São Paulo: Nova Cultural, 1987.

SCHAMA, Simon. Cidadãos: uma crônica da Revolução Francesa. São Paulo: Companhia das Letras, 1989.

SOBOUL, Albert. Dictionnaire historique de la révolution française. Paris: Presses Universitaires de France, 1989.

TACKETT, Timothy. Le roi s'enfuit: Varennes et l'origine de la Terreur. Paris, La Découverte, 2004, 2007.

VOLTAIRE. Democracia. In: Dicionário Filosófico. Seleção de textos de Marilena de Souza Chauí. Tradução de Marilena de Souza Chauí. 2ª ed. São Paulo: Abril Cultural, 1978.

Endereço da Autora:

Rua do Ouro, no 733 - Apto. 204

Bairro Serra

30220-000 Belo Horizonte - MG

patrícia.carvalhoreis@hotmail.com 